\title{
Import substitution in agro-industrial complex as factor of Russian food security
}

\author{
V.V. Moiseev \\ Shukhov Belgorod State Technological \\ University, 46 Kostyukova St., Russia, Belgorod, 308012, \\ din_prof@mail.ru \\ V.F. Nitsevich \\ State University of Management, Moscow, Ryazanskiy \\ prospect, 99. 109542, Russia \\ dr.nitsevich@mail.ru
}

\author{
E.A. Karelina \\ Moscow State University of Technology \\ «STANKIN»1 Vadkovsky lane, Moscow, 127055, Russia \\ opferpriesterin@mail.ru \\ O. A. Sudorgin \\ State University of Management, Moscow, Ryazanskiy \\ prospect, 99. 109542, Russia \\ sudorginoleg@yandex.ru
}

\begin{abstract}
In a difficult economic situation, an important role belongs to the state policy of import substitution. The problems of import substitution become even more urgent in connection with the Western sanctions imposed against Russia in connection with the events in Ukraine. In 2014, several Western countries, led by the United States, announced severe sanctions against the Russian economy. This intensified the process of import substitution in Russia, including both agriculture and processing industries of the agro-industrial complex. In this regard, there has been a decline in food imports from abroad and an increase in the growth rate of food production, oriented to the domestic market.
\end{abstract}

The authors make a valid conclusion that an economically literate policy of import substitution in the agro-industrial complex and other sectors of the economy can become a catalyst for overcoming the technical gap, reviving the investment climate, and increasing its own production of food in necessary quantities in accordance with medical norms of consumption.

In this study, the authors not only analyze the main problems of import substitution, but also determine the crucial ways to accelerate these processes in Russia. The article states that, despite numerous difficulties, the policy of import substitution in the agrarian and industrial complex of modern Russia has all chances for success.

Keywords-agro-industrial complex, food security, import substitution problems.

\section{INTRODUCTION}

It's no secret that in the supply of food for Russian people, the major part now falls on imported goods. In order to reduce Russia's dependence on food imports and thereby raise the country's food security, the political leadership has adopted a program of import substitution in the agro-industrial complex (AIC). It supposes import substitution by goods produced by domestic producers within the country.
The problem of import substitution in the agrarian sector has become more relevant not only with the introduction of Western sanctions, but with a sharp devaluation of the national currency, as well as with the food embargo established by the decrees of the President of the Russian Federation. The first presidential decree of August 6, 2014, No. 560, "On the Application of Certain Special Economic Measures to Ensure the Security of the Russian Federation" imposed a ban on the import of agricultural products from countries that imposed sanctions on Russia (the United States, the EU, Canada and Japan). The second decree was signed by Russian President Vladimir Putin on November 28, 2015 "On Measures to Ensure the National Security of the Russian Federation and Protect Citizens of the Russian Federation from Criminal and Other Illegal Actions and the Application of Special Economic Measures against the Republic of Turkey" [2]. The decree imposed an embargo on the supply of goods from Turkey: vegetables, fruits and other food products to the territory of Russia.

Many economists and political scientists argue that the current plight of Russia's agriculture, the prevalence of imports and the rise in food prices are a consequence of the agrarian policy implemented during the Yeltsin reforms. The result of these reforms was the massive bankruptcy of collective farms, the outflow of the active part of the labor force from the village, and the reduction of acreage by 41 million hectares.

Currently, only $40 \%$ of agricultural land is actually used, half as much as in the USA. The average grain production per capita in Russia decreased more than 2 times in 1990-1999, production of meat - 3 times, of milk - 1.5 times; the total volume of all agricultural products as a result of the Yeltsin reforms decreased by $45 \%$. Due to lack of funding for the years of reforms, the number of cattle decreased almost threefold. If in 1988 there were 59.8 million, today the Russian livestock does not exceed 20 million heads. The decline in the number of livestock led to a decrease in beef production from 4.3 million tons to 1.7 million tons, or 2.5 
times. A further reduction in the number of cattle led to the fact that today consumption of beef has declined in Russia from $29.3 \mathrm{~kg}$ to $11.9 \mathrm{~kg}$ per capita [3]. It is especially sad that Russia has drastically reduced the number of dairy herds. If in 1990 there were 20.5 million cows in our country, then in 2015, according to the chairman of the Council of the Dairy Union of Russia A. Ponomarev, there were only 8.8 million cows [4]. Thus, over 25 years of reforms, thanks to the new agrarian policy, it was possible to reduce the dairy herd of the country by 2.5 times. Of the 39.2 million pigs that were numbered in 1988, the losses amounted to 23.1 million. Our country did not know such ruin even during the Great Patriotic War: after devastating battles, the occupation of a significant part of the territory by the Nazi invaders in the USSR remained in live 12.9 million cows, which is 4.1 million more than in the Russian Federation there are in peacetime [5].

For comparison: in the US there are more than 92 million heads of cattle today. Applying advanced technologies, this country annually harvests 4 times more grain than our country (340-350 million tons); it produces 5 times more meat than the Russians [5]. These successes in the development of the agroindustrial complex of the world power became possible due to the good quality of public administration, well-established interaction between the authorities and business. The US Food Security Act, in force since 1985, confirmed the state's attitude to the agro-industrial complex as a special branch of the economy of strategic importance. For decades, the state has been providing all-round support to its agriculture, while maintaining a policy of broad subsidizing of the two-milliondollar community of farmers at the expense of budgetary funds. In turn, the agrarian sector of this country with its wellfunctioning work allows to ensure food security and US leadership in world food trade. The priority of US agrarian policy remains the provision of guaranteed access of the Americans to healthy and nutritious food with increasing food aid to families with low incomes [6].

In modern Russia, despite the import of foodstuffs, to some extent supplementing the missing own production, there is a serious lag not only from the US, but also from the norms of consumption for meat and meat products, milk and dairy products, vegetables and fruits, and other food.

In the next Presidential Address to the Federal Assembly, with which Russian President V.V. Putin spoke on March 1, 2018, marked a dramatic improvement in the situation with food in the country, reducing dependence on imports. "Back in the early 2000s, we seriously depended on the supply of imported food," stated President V.V. Putin. - The situation has radically changed "[7]. However, Rosstat's data leaves no hope of believing the speechwriters and numerous presidential advisors who prepared his next message to the Russian elite and the people. So, according to the Federal State Statistics Service and the Russian Accounting Chamber, in 2014, beef imports amounted to $60 \%$, the share of pork imported from abroad reached $31 \%$, poultry meat - $13 \%$, cheese was imported to $48 \%$ of the total consumption by Russians, and the share of imports of milk and dairy products reached $60 \%$ [8]. "Virtually all directions of the AIC production are totally dependent on imports," A. Ponomarev, a member of the State Duma Committee on Agrarian Issues, said. If in 2000 the total food imports in the Russian Federation did not exceed 7.4 billion US dollars, then 13 years later, in 2013, it grew 6 times to 43.5 billion dollars [9]. But this huge amount of money could be spent on the development of domestic agriculture and then everyone would benefit from it: both the agrarians, the country's budget, and ordinary Russians. But, unfortunately, hundreds of billions of rubles in terms of currency went to foreign producers instead of supporting the domestic producer. As a result, the number of livestock fell sharply and the defectiveness of such agrarian policy became apparent even to economists. Therefore, there is a lot of work to be done for many years [4].

The situation with import substitution did not improve in 2015. This conclusion is confirmed in the report of the Accounts Chamber of the Russian Federation "On the Federal Budget for 2015 and for the Planning Period 2016 and 2017". In the section of the report devoted to problems in the agroindustrial complex, it was stated that the limited opportunities of Russian agrarians would not allow to replace products from the USA, Canada, the EU, Norway and Australia, against which Moscow imposed sanctions, in the nearest future. The biggest problems with import substitution arise with some types of meat and dairy products. The Accounting Chamber, referring to Rosstat's data, reported that in 2013 the level of free production capacity in the meat processing industry was about $34 \%$. In cheese production in 2013, the level of free capacity reached $41 \%$, while $48 \%$ of the total volume of consumption by Russians of this product was imported [8]. The most noticeable gap in the dairy industry. However, it will be problematic to load even the available production capacities, as some products are produced using raw materials from countries for which counter-sanctions and a ban on imports to Russia have been introduced. It should be remembered that these restrictions on food imports were introduced by presidential decrees No. 560 of August 6, 2014, "On the Application of Certain Special Economic Measures to Ensure the Security of the Russian Federation" of November 28, 2015, No. 583, "On Measures to Ensure the National Security of the Russian Federation and Protect Citizens of the Russian Federation from Criminal and Other Illegal Actions and the Application of Special Economic Measures against the Republic of Turkey"[1,2].

The ban on import of foodstuffs in connection with the embargo became the most ambitious restriction on the import of agricultural products since the beginning of the implementation of the Russian policy on import substitution. The reduction in the volume of food imports in accordance with the imposed embargo orders is shown in the following table. 
TABLE I. REDUCTION OF FOOD IMPORTS TO RUSSIA IN ACCORDANCE WITH INTERNATIONAL DECREES*

\begin{tabular}{|c|c|c|c|}
\hline Indicators & $\begin{array}{c}\text { Total import } \\
\text { (tons) }\end{array}$ & $\begin{array}{c}\text { Decrease of } \\
\text { imports due to } \\
\text { embargo (tons) }\end{array}$ & $\begin{array}{c}\text { Percentage } \\
\text { of countries } \\
\text { embargoed }\end{array}$ \\
\hline Pork & 619700 & 450800 & $72,7 \%$ \\
\hline Poultry & 522800 & 338700 & $64,8 \%$ \\
\hline Cheese & 416573 & 249880 & $60,0 \%$ \\
\hline $\begin{array}{c}\text { Fish and seafood } \\
\text { Milk and dairy } \\
\text { products }\end{array}$ & 1014300 & 530500 & $52,3 \%$ \\
\hline Cattle meat & 9433300 & 3640000 & $38,5 \%$ \\
\hline & 654700 & 59000 & $9,0 \%$ \\
\hline
\end{tabular}

It follows from the table that the greatest reduction in food imports from countries affected by Russia's response to Western sanctions was for pork meat $(72.7 \%$ of total food imports), poultry meat $-64.8 \%$, cheese $-60 \%$ and fish with seafood $-52.3 \%$. To a lesser extent, the import from these countries of vegetables - $29.6 \%$ and meat of cattle - was reduced by $9 \%$.

The ban on imported food, introduced to ensure Russia's security, should become, in the opinion of its initiators, an effective measure of support for the Russian producer. However, the implementation of these decrees not only limited the importation of food into the country, increasing food prices, but also caused considerable damage to the Russian state budget. According to Deputy Minister of Agriculture of the Russian Federation Dmitry Yuriev, only 6,600.7 billion rubles are required to substitute imports for counteracquisitions [10]. However, there also appeared some positive aspects: after Russia had imposed a ban on the import of a number of European, American, Canadian, Japanese and Australian food products in response to Western sanctions imposed in connection with the events in Ukraine, import substitution in the agro-industrial complex acquired great urgency and was noticeably intensified.

\section{PRoblem Statement}

On December 19, 2014 in the "State Program for Agricultural Development and Regulation of Agricultural Products, Raw Materials and Foodstuffs for 2013-2020", adjustments were made related to import substitution and ensuring Russia's food security in the conditions of Western sanctions. The volume of planned budget financing is impressive. So, for 2015 it was supposed to allocate 187.864 billion rubles from the state budget, 2018 - 258.140 billion, 2020 - 350.363 billion [11]. It cannot be stated for sure that all the planned financial resources will indeed be allocated, but the fact itself that the state finally seeks to channel more and more resources to the agro-industrial complex cannot but rejoice.

* The table was compiled by the authors on the materials of the open press.
It should be noted here that along with the budgetary allocations to the agro-industrial complex, the inflow of borrowed funds is increasing due to loans and subsidizing interest rates. Only Rosselkhozbank during the period of the State Development Programs of the AIC issued 2.3 trillion rubles to the rural business. More than $34 \%$ of this amount are investment loans granted for the construction and purchase of fixed assets, the development of livestock complexes, poultry enterprises and other purposes [12].

Investments in import substitution and the development of domestic agribusiness could be more significant if the country's leadership managed to convince big business to abandon the export of capital from the country to offshore and the economy of other states. According to estimations, businessmen have withdrawn more than $\$ 680$ billion or almost three annual budgets of the Russian Federation from our country over the past eight years [13]. The state and business, acting jointly within the framework of approved import substitution programs, could spend trillions of rubles on the development of agriculture, the return of tens of millions of hectares of arable land, the production of new modern machinery and equipment for the agro-industrial complex, the construction of new farms and fattening complexes, infrastructure, conditions of rural workers, etc.

It should be noted that investments invested in animal husbandry are not returned to Russia in 10 years, and there are many risks associated with bureaucracy and corruption [14]. Therefore, this niche, although attractive for business, is being mastered at an insignificant rate because of the shortage of "long-term" money, and for a quarter of a century the dairy herd has shrunk. Without developing specialized cattle breeding, Russia will remain a country importing beef, the Meat Livestock Development Strategy until 2020 says [15].

As a result of the state program for the development of the agro-industrial complex, by 2020 the following figures are supposed to be reached: it is planned to increase the country's own grain production to $99.7 \%$, production of beet sugar to $93.2 \%$, of vegetable oil - to $87.7 \%$, of potatoes - to $98.7 \%$, of meat and meat products - up to $91.5 \%$, of milk and dairy products - up to $90.2 \%$. These indicators not only correspond, but also slightly exceed the boundaries established by the Doctrine of Food Security of the Russian Federation, approved by Presidential Decree of January 30, 2010, No. 120, which provides for self-sufficiency of basic food products by 80 $95 \%$, including grain - by $95 \%$, sugar by $80 \%$, vegetable oil by $80 \%$, meat and meat products by $85 \%$, by milk and milk products by $90 \%$, by fish products by $80 \%$, by potatoes by $95 \%$ and by food salt by $85 \%$ [16].

The Russian agribusiness should achieve such impressive indicators by 2020 . With the implementation of the planned plans and programs, including import substitution, our country's food security will be significantly strengthened. However, as practice shows, not everything that has been planned can be really achieved, and this has not only subjective, but also objective reasons. So, according to the exMinister of Agriculture of the Russian Federation A. Tkachev, Russia will be able to fully meet its needs for pork and poultry meat for two to three years, to switch to full provision of 
Russian consumers with domestic fruits and vegetables within three to five years. "As for milk and dairy farming, the situation is more complicated, it will require for serious investments and subsidies, according to our estimates, of the order of 7-10 years" [17]. Russians have to rely on the promises of the former minister of agriculture and tighten their belts with the rise in prices for imported and domestic beef, cheese, milk and other food products.

As Russian practice shows, food is growing in price every year, far outstripping official inflation. So, according to Rosstat, food in 2015 compared with 2014 rose in price by an average of $20 \%$. Leader on the increase in prices were cereals and legumes - for 9 months of 2015 they went up by $46.8 \%$; sugar added $44.1 \%$ to the price. Fruits and vegetables rose by $31.3 \%$, fish and seafood - by $29.9 \%$, sunflower oil - by $29 \%$. Milk and dairy products, including butter increased by 14.1 $14.4 \%$, the cost of meat and poultry increased by $16.5 \%$ [9]

The country's agriculture, which is part of the agroindustrial complex, needs tens of thousands of new combines, tractors, trailed equipment to carry out spring-field work and harvesting in a tight agrotechnical period of time. It's no secret that, due to the shortage, e.g. of proper combine harvesters, the country loses millions of tons of grain during the cutting of grain crops.

At present, the Russian agribusiness sector has got over 435,000 tractors, 134,000 harvesters and 19,000 self-propelled harvesters. According to experts, the share of old combines and tractors in the agro-industrial complex of Russia is about 70-80\%. Therefore, in 2012 the government approved a program for the dismantlement of old agricultural equipment and allocated 3.5 billion rubles for Rosagroleasing, but this money was enough to purchase only 2,000 pieces of equipment. Therefore, the issue of large-scale re-equipment of Russian agricultural enterprises remains open.

The head of the Russian government, D.A. Medvedev, acknowledged that production volumes and the pace of renewal of the country's machinery and tractor fleet are still insufficient. On the level of mechanization of labor, our agricultural producers are still inferior to their colleagues from leading countries. If the load on one combine in Russia is 354 hectares, in the USA it amounts to 63 ha, in France - to 53 ha [18]. We emphasize that such a load is distributed not only to new machinery but also to all worn-out agricultural one, which is three quarters of the total machine-and-tractor park of the agro-industrial complex. Under such conditions, it would be advisable for the government to allocate funds for the production of domestic agricultural machinery that is not inferior in quality to imported samples, including this position in the approved state program on import substitution.

For the successful implementation of import substitution plans and programs in the conditions of severe sanctions in the agro-industrial complex of Russia, it is necessary to solve a large number of urgent and multifaceted tasks in order to make a breakthrough in providing Russians with the necessary foodstuffs, as determined by the head of state in the decree of May 7, 2018. One of the most important tasks in this direction is equipping farmers with new equipment of their own production, which is not inferior to Western models in terms of technical characteristics.

Without a serious increase in domestic production in modern Russia, it is impossible not only to reduce food prices, but also to solve the food problem.

\section{RESEARCH QUESTIONS}

In this study, the authors focus on the following issues:

1. Determining the causes of food imports in its dynamics in recent years.

2. Analysis of the main directions of the state policy of import substitution in the agro-industrial complex in modern conditions.

\section{PURPOSE OF THE STUDY}

The purpose of the study is to study the problems of import substitution in the agro industrial complex and, on this basis, to offer recommendations for the implementation of the planned programs in the conditions of Western sanctions.

\section{RESEARCH METHODS}

When studying the main aspects of the topic, the authors use the following methods: 1) the institutional method that allows analyzing the role of the president, government, other authorities in implementing the state policy of import substitution; 2) the systematic approach that allows one to form a holistic and objective view of the state of import substitution in the agro-industrial complex of Russia, to note both the positive aspects and the existing shortcomings in the implementation of state policy in this area; 3) the method of comparative analysis was used by the authors to compare the level of food security in Russia and the United States; 4) the study also used methods of content analysis, statistical and other methods of determining current trends in the implementation of the state policy of import substitution in the agro industrial complex of Russia.

\section{FINDINGS}

1. In connection with economic sanctions in the Russian economy, the priority task is to produce domestic agricultural products, which will not yield to imports in terms of quality and price.

2. The arguments and facts presented in this article convincingly testify to the correctness of the policy of import substitution in the agro-industrial complex with the aim of restoring the lost food and economic independence of Russia, as well as providing Russians with quality food products of their own production.

3. The solution of the problem of import substitution is possible if the intensity of production of domestic agricultural products is increased based on the introduction of innovations and investments, the use of new and more productive technologies, and the development of the food and processing industry that "form the agrifood market, food and economic security." 
4. In the context of limited state support for the agroindustrial complex, the need to apply targeted import substitution programs is significantly increasing, since it allows one to ensure the comprehensive and systematic solution of the food problem, provide targeted support to program participants through their competitive selection, monitor the targeted use of allocated funds for the production of domestic foodstuffs in exchange for imported ones.

5. Products of Russian manufacturers became more competitive on the foreign market due to the depreciation of the ruble. This should be used to the maximum to support the effect of import substitution. For successful implementation of import substitution programs in the agro-industrial complex, the authorities promised to reduce the key interest rate. For agrarians during the sowing season and harvesting, it will regularly decline, which is very important for ensuring the volume of planned agricultural work, as well as reducing the cost of future commercial products.

6. Banking and credit organizations should focus their activities not only on large economic entities, but also on medium and small businesses that have limited access to credit resources.

\section{CONCLUSION}

For the real revival of domestic agriculture, the implementation of import substitution programs, in our opinion, it is required to carry out the following measures:

- write off all the debts of agricultural enterprises, reduce taxes, thus freeing them from puffed weights on their feet;

- develop agricultural cooperation in every possible way, to help co-operatives with preferential loans and equipment;

- pay a subsidy on the products produced, as is customary for farmers in the United States and a number of European countries;

- compensate a part of expenses for fuel, fertilizers, new equipment, since the disparity of prices leading to the robbing of farms, as in the years of the first five-year plans, has become too large;

- restore privileges for young specialists who have started working in the countryside, including providing them with housing;

- help start-up farmers and other agricultural producers in marketing issues, in promoting their products to the market;

- direct the investments not only to the re-equipment of agricultural production, the modernization of machinery, construction of farms, workshops and storage facilities, but also to equipping the village, creating human conditions for work in order to make rural labor prestigious for young people to work in this industry;

- renew the state order for agricultural products; the state in the person of the Ministry of Agriculture should guarantee to the peasants that at least 75 percent of the grain, milk, meat produced at them are sold at market prices through procurement offices and purchasing cooperatives, etc.
As practice has shown, the main incentive for Russian agricultural producers is the guarantee of sales of grown products and participation in the implementation of programs and plans for the replacement of imported products. In order to support agrarians, the state needs to establish firm purchasing prices for agricultural products, which should not be lower than market prices, in order to stimulate the increase in volumes. This is how the country's agriculture was raised after the devastating wars in the USSR and a number of other states. If a farmer has an incentive, he will expand his crops, and if not, he will cut back so as not to work at a loss.

Only by increasing the financing of the Russian agribusiness and by investing considerable funds in its development, one can seriously talk about import substitution, also about filling stores with domestic food products and ensuring the food security of our state.

Thus, in order to solve the problems associated with the development of the agro-industrial complex and import substitution in the new political and economic conditions caused by the next crisis and Western sanctions, there is a need for a radical review of the agrarian policy of the Russian state.

The policy of import substitution in the agrarian sector of the economy, the message and the May (2018) decree of Russian President Vladimir Putin in this sphere will be shown by the time and actions of the new Russian government.

\section{References}

[1] The Decree of the President of the Russian Federation from August 6 2014, vol. 560 "On the Application of Certain Special Economic Measures to Ensure the Security of the Russian Federation". URL: http://base. garant.ru /70711352/\#ixzz3sF9AOjBB

[2] The Decree of the President of the Russian Federation from November 28, 2015, vol. 583 "On Measures to Ensure the National Security of the Russian Federation and Protect Citizens of the Russian Federation from Criminal and Other Illegal Actions and the Application of Special Economic Measures against the Republic of Turkey". URL: http://kremlin.ru/acts/news/50805

[3] I. Ganenko, "New Russian beef”. URL: http://www.agroinvestor. ru/markets/article/12128-novaya-russkaya-govyadina/

[4] A. Ponomarev, "On the emerging situation with import substitution in the agroindustrial complex". URL: http://agroinfo.com/a-ponomarev-oskladyvayushhejsya-situacii-s-importozameshheniem-v-apk-2608201 $502 /$

[5] The number of cows in Russia and the USSR. URL: http://wedmack.livejournal.com/644148.html

[6] Food security of the US and Russia (condition and prospects). URL: http://gendocs.ru/v11056/\%D0\%B0\%D0\%BA\%B8?page=9

[7] The President's (2018) Address to the Federal Assembly. URL http://kremlin.ru/events/ president/news/56957

[8] Russia can not cope with a complete substitution of imports of products. - URL: http://old.ibusiness.ru/blog/novosti/35288

[9] S.N. Glagolev, V.V. Moiseyev, "Import substitution as a factor in the development of Russia's agro-industrial complex printed", Bulletin of BSTU named after V.G. Shukhov, vol. 3. pp. 195-200, March 2016.

[10] To replace imported products that fall under the Russian counterforce, it will take more than 600 billion rubles. URL: http://www.gazeta.ru/business/2014/10/04/6247581.shtml

[11] M.N. Shaternikov, V.V. Moiseev, (2016). "Problems of food security in the face of Western sanctions". Bulletin of BSTU named after V.G. Shukhova, vol. 6 pp. 242-246. June 2016. 
[12] Rosselkhozbank sent 2.3 trillion rubles to finance State programs for the development of agriculture. URL: https://pg11.ru/companies/30783

[13] V.V. Moiseev, "Actual problems of import subsumption in modern Russia”. Danish scientific journal, vol. 6, pp. 24-29, June 2017

[14] V.V. Moiseev, V. Sh.Guzairov, V. A.Vasneva, "To Question about Struggle Against Corruption in Russia". The Social Sciences, vol. 10 (3), - pp.265-272, June 2015.

[15] Order of the Ministry of Agriculture of the Russian Federation of August 10, 2011 vol. 267 "On the approval of the strategy for the development of meat production in the Russian Federation until 2020". URL: http://www.mcx.ru/documents/document/show/16974.133.htm

[16] Strategy of development of food and processing industry until 2020. URL: https://gov.spb.ru/static/writable/ckeditor

[17] Prospects of import substitution in agriculture in Russia. URL: https://gov.spb.ru/static/ writable / ckeditor

[18] Agrarians do not have enough equipment. URL: https:// gov.spb.ru/static/ writable / ckeditor 